\title{
Market Chain Analysis of Coffee in Gimbo Woreda, Kaffa Zone, Snnpr, Ethiopia
}

\author{
Anwar Muzemil \\ Bonga University, Department of Agricultural Economics
}

\begin{abstract}
Market chain analysis of coffee production in Gimbo woreda, Kaffa zone, SNNPR, Ethiopia. The study identified the main marketing actors, which are producers, wholesalers, retailers, processors, and consumers. The result of the assessment of the market structure indicated that the four firm's concentration ratio (CR4) was 39.7\%, which show there is a weak oligopoly in the market structure of coffee in the area. Lack of working capital was the main barrier which protects peoples from interring into this business. The survey result indicated that the price-setting technique in the coffee market is largely determined by the benevolence of purchasers. Producers have a low bargaining power to influence price because of their small supply and low access to market (price) information. The study result shows that the majority of coffee producers $(64.7 \%)$ supply their product to the market at the time when they need money. In evaluating the market performance, the marketing margin analysis result showed that processers $(21.74 \%)$ take the largest marketing margin in the coffee market chain. The rest $13.04 \%$ and $8.70 \%$ of marketing margin were received by wholesalers and retailers respectively. Ordinary least square regression was employed to identify factors influencing the level of coffee market participation in the study area. Eleven explanatory variables were hypothesized to analyze factors that affect the level of farmer's participation in the coffee market. The OLS analysis result shows that Among Eleven explanatory variables, only two variables (Income from off-farm activities and Quantity of coffee produced) were found to significantly affect the level of coffee market participation.
\end{abstract}

Keywords: Structure-conduct-performance, Market concentration, Marketing Margin, Gimbo woreda

DOI: $10.7176 /$ EJBM/13-9-05

Publication date:May $31^{\text {st }} 2021$

\section{Background}

In Ethiopia, the livelihood of smallholder farmers depends on agriculture especially in the production and marketing of cereals. These crops cover about $80 \%$ of countries' total cultivated land and which creates about $40 \%$ of rural employment. It accounts for More than $40 \%$ and $60 \%$ of household's food expenditures, and total caloric intake respectively (CSA, 2017). Hence, the development of agriculture is important for addressing different socioeconomic problems.

Among different crops produced in the world, coffee is the one and the most important crop. It has a great role in the world economy and the production process is different in different areas. In Ethiopia, different crops are supplied to different countries among those crops' coffee takes the leading part it generates the largest foreign currency to our economy. In the rank of countries, coffee production Ethiopia takes the fifth and first levels in the world and in Africa respectively. Different coffee species are originated in different countries, Arabica coffee is originated in Ethiopia. The production of coffee needs many laborers (labor-intensive) (ECEA, 2013).

Generally, the agricultural sector contributes a large part to the Ethiopian economy, the coffee sub-sector plays the leading part in the country's economy it accounts for about 35\% foreign currency earned through agriculture and $4 \%$ of the total finished agricultural products (GDP). In the production process of coffee, it needs numerous labor (i.e. It creates job opportunities for many peoples). It is a source of income about fifteen (15) million peoples in Ethiopia, they participate in different parts of the coffee sector, like producers, processors, traders, transporters, exporters. And also it generates income for the government through tax in the sealing of coffee (Ministry of Trade, 2012).

The contribution of an effective and efficient market supply of agricultural outputs in inspiring production has greater. It also increases the price that farmers obtain from consumers by reducing the number of middlemen, by reducing misconduct in the market channels, and by lowering marketing costs, through this way it accelerates the growth of countries' economies. Marketing channels for agricultural outputs in underdeveloped countries were complex and large which leads to high west, transaction costs, and lower producer's income (Panda and Sreekumar, 2012).

Smallholder farmers dominate the production of coffee, they produce the largest percentage among the total production they produce over $95 \%$ of the total coffee output. And the amount of coffee supplied by each farmer was small. This small supply of coffee leads to high transaction costs which discourage farmer's participation in the coffee market and reduces farmer's incentive to produce more. There are different marketing channels are available for coffee marketing. The profit obtained and the cost incurred by coffee producers are different in different marketing channels. So choosing an appropriate marketing channel is a crucial factor for the marketing 
of any product. At the time of choosing to market channels considering different factors like risk availability, sales volume, cost requirement, etc. is important (Le Roux, et al. 2010).

The marketing of coffee in Ethiopia is constrained by various problems. Some of those main problems are the unfavorable price of coffee in an international coffee market, availability of high transaction costs, shortage of adequate coffee processing and handling facilities, general government control of coffee examination and grading scheme, and a shortage of skill of coffee export marketing and irregularity in coffee quality (ECXA, 2008).

\subsection{Statement of the problem}

The market for agricultural products in Ethiopia was dominated by small-scale farmers, and there are high transaction costs and risk and also low market information access (ECX, 2011). The government and other bodies dealing with the marketing of coffee, but still, there is the problem of the poor performance of coffee and other agricultural products marketing (Aklilu and Ludi, 2010). Different studies tell us that the performance of our Ethiopian agricultural markets was not strong. This weak performance is a major problem to the growth of the universal economy especially to the growth of agricultural subdivisions (FAO, 2011). Even though production is increasing, without efficiently marketing the surplus outputs both the producers and consumers are not benefiting from the surplus output obtained from increased production (Jema, 2008).

In order to transform coffee from the point of production to the necessary market at the minimum cost, it requires the presence of an efficient marketing mechanism. In a market, there is a number of channels are available as a result of identifying and selecting efficient and least cost marketing channel is important. This can be done by making appropriate studies. Different market chains exist in different coffee-producing parts of Ethiopia. In several areas, the coffee market chain is long and complex as traders, wholesalers, brokers, and retailers are common in the chain of this vital product.

Knowing the kind of marketing channel chosen by smallholder farmers was an important factor in order to make an effort to detect interferences that could encourage farmer's participation in coffee marketing, (Jari and Fraser, 2009). Providing an efficient market for farmers by constricting suitable market infrastructure it is easier for producers to supply their products is also believed to be essential for improving the level of commercialization, particularly in third world countries (Shilpi and Umali, 2008). Though the livelihood of many peoples living in Ethiopia is based on agriculture especially on coffee, empirical studies on market chain analysis of coffee production are not many. Earlier studies conducted on coffee marketing in Ethiopia are frequently focused on one channel. Such as, (Tinsae, 2008) investigated the performance of primary coffee cooperatives in Wonago and Yirga Cheffe woreda. And (Demeke, 2007) investigated the performance of coffee marketing cooperatives and members' satisfaction in Dale district, Southern Ethiopia. These studies were done only in a single market chain (cooperatives).

Farmers In the study area (Kaffa Zone) they produce many crops, but the main cash crop is coffee and the livings of smallholder farmers are greatly dependent on coffee. This study aims to find out the general socioeconomic characteristics and livelihood activities, to identify major coffee marketing channels available in the area, and to identify the major determinants of the volume of coffee supplied by farmers using an econometric approach. To the best of the author's knowledge, the shares of the channels and factors determine the amount of coffee supplied by farmers has not been studied in the study areas. Therefore, it is important to carry out an empirical study to fill this information gap by identifying the major channels available in the area and determinants of the level of market participation of those farmers.

\subsection{Objectives}

The General Objective of the thesis was market chain analysis of coffee in Gimbo woreda, Kaffa zone, SNNPR, Ethiopia

Specific objectives are:

$\checkmark \quad$ To describe key coffee marketing channels that exist and used by producers and traders in the area.

$\checkmark$ To analysis the coffee market structure, conduct, and performance in the area.

$\checkmark$ To analysis factors that affect the level of farmers participating in the coffee market

\subsection{Significance of the Study}

The findings of this paper would be beneficial to offer important information on the Coffee market chain in Kaffa Zone; it helps farmers to choose the appropriate market chains for reducing transaction costs and increasing their benefit obtain from coffee and government and NGOs in developing a good strategy for implementing different improvement activities. All participant who benefited from this sector gets support from the findings of this paper to make good decisions in any way. It also used as a source of reference for future investigations and reviews

\section{Materials and Methods}

Study Area: This study was undertaken in Gimbo woreda, Kaffa zone, SNNPR, Ethiopia. Gimbo is one of the 
woredas of the Kaffa zone and most of the land is covered by forests. Geographically the study area is located between $7020^{\prime}$ to $7040^{\prime} \mathrm{N}$ latitude and $35048^{\prime}$ to 360 14' E longitude. Gimbo is located in the southern part of the country at a distance of $436 \mathrm{~km}$ from the capital city of Ethiopia Addis and $24 \mathrm{~km}$ western from the Zonal city of Bonga. The total human population of the woreda has 89,892 of which 44,774 and 45,118 are males and females respectively. Some population or about $10.69 \%$ exists in urban. Most of the people live in the area whose religion was Orthodox (87.17\%), 5.14 \% of the population are Muslims, $4.01 \%$ are protestant and 3.14\% are catholic (CSA, 2007). Ethnically, there are many ethnic societies in the area, but Kafficho, Amhara, and Oromo ethnic societies are taking the large number they accounted for about $76.74 \%, 15.19 \%$, and $4.25 \%$ of the total population, respectively.

The main livelihood activity in the area was agriculture, their economy depends on agriculture. There are also other economic activities that exist like trade, manufacturing, and tourism, but most of them are dependent on agriculture. The agricultural production system conducted in the area was a mixed agricultural system. In a mixed agricultural system, they produce different crops (i.e. enset, maize, wheat, barley, and coffee), vegetables, and fruits (banana, orange, and avocado, etc.), and animals (cattle, sheep, and goat). Almost all households live in Gimbo woreda they produce coffee, and it highly supported their livelihood.

Data Type and Method of Data Collection: Regarding different variables two types of dates were used in this study, which are primary and secondary data. These data help us to know the marketing characteristics, participants in the marketing channel, factors that affect supplied volume, and available channels of coffee in the area. The data were obtained from different sources (literature, reports, governmental and non-governmental organizations, traders, and farmers). From literature, reports, and governmental and non-governmental organizations we obtain secondary data through interviews, online searches, etc. From traders and farmers, we obtain primary data regarding socio-economic and other factors, types of traders, the strategies they use to buy and sell their products, etc., through questioners and direct observation.

Sampling Procedure: firstly among all Kebeles available in the Kaffa zone Gimbo woreda was selected purposively based on its capacity for coffee production and marketing. Secondly from the available Kebeles of Gimbo woreda four Kebeles were selected randomly, because socioeconomics conditions, production and marketing of coffee, and other factors are relatively the same in both Kebeles of the woreda. Finally, 155 sample households were randomly selected from those four Kebeles. According to Yemane (1967) formula as shown below sample size was 155 :

$$
n=\frac{N}{1+N * e^{2}} \quad \mathrm{~N}=18,224, \mathrm{e}=0.08 \quad n=\frac{18224}{1+18224 *(0.08)^{2}} \quad n=\frac{18224}{117.6336} \quad=154.923 \quad \underline{\mathrm{n} \approx 155}
$$

Traders' survey: Different from selection farmers, sampling of traders is somewhat complicated for the researcher. Because traders are move from one please to another and identifying the type of trader is also difficult due to the unavailability of clear criteria. But I was tried my best to take good and appropriate levels of representatives. The serve for traders was undertaken in the market available in towns in which coffee traders found. On the center of the flow of coffee, three markets (Gimbo, Gojeb, and Bonga town) were chosen purposely, which are the highest coffee marketing places. Similarly, a simple random selection technique is used to choose traders. The entire number of respondent traders was 20. The sample included licensed and unlicensed market participants.

Methods of Data Analysis: After the collection of data I used descriptive and econometric analysis technics to the analysis of the collected data.

Descriptive analysis technics are ratios, percentages, means, and standard divisions. These methods are used to analyze the socioeconomic factors, marketing channels, and market characteristics.

Market Channels: The combination of those chains in which the coffee product was moved from the farm get to final consumers. All the available market participants through which the coffee product is moved into the final consumption and the role of each actor within the channels was investigated.

Structure of the market: in this study market concentration and barriers to entry were investigated. Market concentration means the number and magnitude of purchasers and suppliers in the marketplace, the goal of firms, business entry obstacles, firm's economic advantages, and firms' expectation about their competitors is very important when we determine the concentration ratio, activities, and performance of businesses. When the concentration ratio is high which tells us that there is low competition in the market. The concentration ratio was calculated using a formula:

$\mathrm{MS}_{\mathrm{b}}=\frac{V b}{\sum_{i=1}^{n} V i}$

Where $\mathrm{MS}_{\mathrm{b}}$ - buyers' market share

$\mathrm{Vb}$ - the total amount of buyer b product

$\Sigma \mathrm{Vi}$ - the total product in the market

$C=\sum_{b=1}^{r} S b$

Where $\mathrm{C}$ is concentration ratio 
$\mathrm{Sb}$ is the percentage of the product controlled by firm $\mathrm{b}$ $r$ - Number of biggest businesses firms we use to calculate the concentration ratio.

The popular concentration ratio was a four-firm concentration ratio (calculating the total share of the largest four firms). When the concentration ratio is equal to or greater than $50 \%, 33-50 \%$ and less than $33 \%$ which shows a strong oligopoly, week oligopoly, and competitive market in the business respectively, Kohl's and Uhl (1985).

Market conduct: In the market conducts the price behavior, the buying and selling condition was investigated. It is the overall relationship between buyers and sellers in the market. The price-setting mechanism on how the price of goods is determined in the market. In some markets the price of goods was set by bargaining in another market the price was set by buyers or sellers alone and in some other markets, it was set by the market demand and supply. And also for whom producers sell their product in the market is also investigated in the market conduct.

Market Performance: The market structure and conduct in the general chain of coffee is basically determined the market performance and it was described in terms of the marketing profit margin that each participant gets from the ending of the price paid by the last users. So in order to compute the marketing margins for each agent in the chain, it is vital to clearly recognize the chains of the product.

Marketing Margin- it is used to identify the price difference between producers and end-users for identical products. It also describes the price difference in other chains in the market, for instance among producer and wholesale, wholesale, and retail prices (Scarborough and kydd, 1992).

The marketing margin was computed by finding the price difference among farmers and end-users. The farmer's share is usually employed ratio computed as, the ratio of farmer's price to the price of end-users. Mathematically, producers' share can be computed as:

Where: PS is Producers' share

$$
P s=\frac{P x}{P r}=1-\frac{M M}{P r}
$$

Px is the price received by Producers

Pr is the price payed by consumer

$\mathrm{MM}$ is marketing margin

From this equation, we realize that when there is a high marketing margin which leads to a low producer share and vice versa.

The total marketing margin is obtained through the method given below

$\mathrm{TGMM}=\frac{\text { end user price } \text {-producers price }}{\text { end user price }} \times 100$

Where TGMM-Total gross marketing margin

$\mathrm{GMMP}=\frac{\text { Price paid by the consumer }- \text { Marketing gross margin }}{\text { price paid by the consumer }} \times 100$

Where GMMP- Producers' participation (farmers' portion)

Econometric analysis: This technique of statistics analysis states that the use of various economic models for analyzing hypotheses related to the objective of the theses.

\section{Factors affecting coffee market supply}

In investigating determinants of the supplied volume of coffee, we use the OLS model if all coffee producers' households in the study area supply their product to the market. Otherwise, we use another model because applying the OLS model by rejecting non-supplier households from the analysis which leads to selectivity bias. Due to that when such situations have happened we use Tobit, Double Hurdle, and Heckman two-stage models to solve such problems. For this paper, a multiple linear regression model was applied to analyze the determinants of the volume of coffee supplied to the market. This model is also chosen for its ease and practical applicability (Greene, 2000). The coffee supply model to be applied in this analysis would have the following form:

$\mathrm{Y}=\mathrm{X}^{\prime} \beta+\mathrm{U}$

Where: $\mathrm{Y}=$ quantity of coffee supplied to market

$X=$ a vector of explanatory variables

$\beta=$ a vector of parameters to be estimated

$U=$ disturbance term

Hypothesis and definitions of variables: In the process of determining factors influencing the level of coffee market supply both continuous and discrete variables were hypothesized based on economic theories and the findings of different empirical studies. Accordingly, in order to investigate the determinants of market supply, the following variables were constructed.

Dependent Variable

Quantity of coffee supplied to the market: It is a continuous variable that represents the dependent variable; the amount of coffee actually supplied to the market by household in the year 2020/21 which is measured in quintal.

Independent Variables: The explanatory variables expected to influence the dependent variable are the following: Quantity of coffee produced: It is an economic factor and continuous variable that can affect the household level marketable supply and measured in quintal. The quantity produced is assumed to affect the marketable supply 
positively, because a farmer that obtains high yield can supply more to the market than a producer who had low yields.

Sex of the household head: This is a dummy variable that takes the value of one of the household head is male and zero otherwise. Both men and women participate in coffee production. Male households have been observed to have a better tendency than a female household in coffee production and supply of coffee due to different discriminating socioeconomic factors in society.

Age of the Household head: It is a continuous variable and measured in years. Since this variable has a direct relation with experience in production, it was assumed that it will have a positive and significant influence on the supply of coffee.

Educational Status of the Household head: It is a dummy variable and refers to the formal schooling of a respondent during the survey period. It has taken dummy values 1 if the household head attended any formal education and 0 otherwise. This variable is also assumed to have a positive and significant impact on the supply of coffee. This is due to the fact that a farmer with good knowledge can adopt better practices than illiterates that would increase marketable supply.

Family Size: This variable is a continuous variable and refers to the number of families of the household. It is assumed that households with larger family sizes can have more labor for his farming activities and higher expenditure for consumption and other expenses.in order to cover this expense they supply a large amount of coffee to the market. Therefore, the variable expected to have a positive relationship with the coffee supply.

Size of land holding: This variable was a continuous variable measured in terms of the number of hectares owned by producers and was expected to affect the household level of coffee marketable supply positively. This is because the larger the total area of the farmland the farmer owns the larger land is allocated for coffee and the higher would be the amount of coffee product. So, this variable expected to affect the level of coffee supplied to the market positively.

Income from off-farm activities: This is treated as a dummy variable and measured as 1 if the household obtained income from off-farm activities and 0 otherwise. This variable was hypothesized to have a negative and significant impact on the supply of coffee. This is because, if the households have off-farm income it covers their expenses, so, it reduces their interest to produce and supply coffee to the market.

Access to market information: This is a dummy variable taking the value of 1 if the producer had access to market information and zero otherwise. It has been hypothesized that it affects the marketable coffee supply of the household positively. The better information farmers have the more likely they supply coffee to the market.

Distance to the nearest market: This is a continuous variable measured in kilometer. The closer a household to the nearest coffee market, the lesser would be transportation costs, loss due to waste, and better access to market information and facilities. This variable is also assumed to have a negative relationship with the coffee market supply.

Livestock holding: This is a continuous variable measured in the tropical livestock unit (TLU). Farmers who have much livestock are estimated to specialize in livestock production so that they allocate a large share of their land for pasture. Therefore, the variable expected to have a negative relationship with the coffee supply.

Ownership of market transport facilities: Specifically vehicles, carts, and transport animals would be used to measure the availability of producing transportation facilities by households. In cases where households owned transportation facilities, the variable took the value of one, and zero if the household did not own any form of transport facility. This variable is expected to have a positive effect on the market supply of coffee. The availability of transportation facilities helps reduce long market distance constraints, offering greater depth in marketing choices.

\section{RESULTS AND DISCUSSION}

This section summarizes the major findings of the study. Both descriptive statistics and econometric analysis were used to analyze the data. Descriptive statistics were employed to describe the demographic characteristics of sample respondents and the structure, conduct, and performance of the market. The econometric analysis was used to identify the determinants of the level of coffee supply in the study area.

Descriptive Analysis

\section{Sociodemographic Characteristics of coffee producers}

This section presents the summary of the sample respondents with regard to their age, sex, education level, family size, land size, off-farm income, market information and distance, number of livestock, and Ownership of market transport facilities.

The Average productivity of coffee was 1.62 quintal per year in the study area, and the range varies between 0.25 and 5 quintals. The survey on age measured in years provided a clue on the working ages of households. It is one of the important characteristics of the respondents, it reflects on the productivity of the population. The age of the head of the household is considered as it has a relation to the experience of the farmers. Old farmers could have many years of experience in coffee production and marketing than younger ones. Experienced farmers 
believed to have a higher knowledge of coffee quality management than others. The average age of the sample households was 44.05 years. Accordingly, the minimum and maximum age of the respondent was 23 and 80 years respectively. The majority of the respondents were found in the most actively working-age category (20-64 years).

The available data indicates that the average family size in the area was 4.24 . According to the survey result in family size in the study area ranging between 1 and 8 ; that means farmers with different family sizes were participating in coffee marketing activities. Bigger family size has supported to boost the volume of supply in the study areas to impact for better participation in the markets. The land is perhaps the single most important factor of production and measure of wealth in the study area. The majority of the respondent's landholding size is not more than 2 hectares. The average land owned by coffee producers was 1.14 hectares, with minimum and maximum landholding size of 0.25 and 3 hectares.

Regarding the distance taken to travel from home to the nearest market place where they sold their coffee product, this is a distance measured in kilometers to reach the nearest coffee market. Sample coffee producing farmers reported that they had to travel an average of $1.70 \mathrm{KM}$ to reach the nearest coffee market. The minimum and the maximum distance that sample coffee producers had to travel to reach the nearest coffee marketing place were 0.10 and $5 \mathrm{KM}$, respectively. Livestock holding is the total number of livestock holding of the household measured in the Tropical Livestock Unit (TLU). Livestock's are farmers' important sources of income, food, and drought power for crop cultivation and transportation. Among 155 sampled households, the average livestock holding was 3.14 TLU, where the maximum livestock holding was 7.30 and the minimum was 1.20.

Table 1. Socio-demographic characteristics of sample households (continues variables)

\begin{tabular}{|l|l|l|l|l|}
\hline Variables & Mean & Std. Deviation & Minimum & Maximum \\
\hline Age of the Household head & 44.0452 & 12.47092 & 23.00 & 80.00 \\
\hline Total Family Size & 4.2387 & 1.53777 & 1.00 & 8.00 \\
\hline size of land holding & 1.1355 & 0.67615 & 0.25 & 3.00 \\
\hline Total Number of livestock & 3.1386 & 1.43981 & 1.20 & 7.30 \\
\hline quantity of coffee produced & 1.6248 & 1.06381 & 0.25 & 5.00 \\
\hline Distance to the nearest coffee market & 1.6865 & 1.04515 & 0.10 & 5.00 \\
\hline
\end{tabular}

Source: Survey result, 2020

Results of the descriptive analysis on the characteristics of the coffee producers show that in the study area, $66.5 \%$ of the sample respondents were male-headed and $33.5 \%$ of the respondents were headed by females. The educational background of the sample household heads is believed to be an important feature that determines the readiness of household heads to accept new ideas and innovations. It is believed that the educational level of the household head has an influence on adapting modern coffee production and marketing systems. The data indicated that only $42.6 \%$ of the sample respondents were literate, and the remaining $57.4 \%$ were illiterate. There are different sources of off-farm income in the study area. From the sample respondents, 55.5\% of the households have off-farm income while $44.5 \%$ of the households did not have off-farm income due to various reasons.

Information is important for enhancing the production and marketing of coffee. Access to agricultural information services makes farmers be aware of and get a better understanding and ultimately leads to a decision to take the risk for improved agricultural practices. In the area, 60.6 percent of sample households were access to market information and 39.4 percent of sample households did not have market information. They were getting market information from different sources, the major source of information was friends/neighbor farmers. Transportation facilities play important role in the marketing activities of farmers. The availability of transportation facilities helps reduce long market distance constraints, transaction costs, and wastes. About 40.6\% of the sample household heads were they owned market transport facilities. However, 59.4\% of the sample respondents don't own market transport facilities.

Table 2. Socio-demographic characteristics of sample households (dummy variables)

\begin{tabular}{|l|l|l|l|}
\hline Variables & & Frequency & Percentage (\%) \\
\hline \multirow{2}{*}{ Sex of the Household Head } & Male & 103 & $66.5 \%$ \\
\cline { 2 - 4 } & Female & 52 & $33.5 \%$ \\
\hline \multirow{2}{*}{ Education status of the household hade } & literate & 66 & $42.6 \%$ \\
\cline { 2 - 4 } & Illiterate & 89 & $57.4 \%$ \\
\hline \multirow{2}{*}{ Ownership of market transport facility } & yes & 63 & $40.6 \%$ \\
\cline { 2 - 4 } & no & 92 & $59.4 \%$ \\
\hline \multirow{2}{*}{ Income from off farm activity } & yes & 86 & $55.5 \%$ \\
\cline { 2 - 4 } & no & 69 & $44.5 \%$ \\
\hline Availability of coffee market information & yes & 94 & 60.6 \\
\cline { 2 - 4 } & no & 61 & 39.4 \\
\hline
\end{tabular}

Source: Survey result, 2020 


\section{Major coffee marketing channels exist and used in the study area}

The major coffee marketing actors

In this study, different marketing actors were identified which participates in the exchange of coffee in the study area. The major marketing actors in the study area were: producers, wholesalers, retailers, processors, and final consumers of coffee.

Producers: Producers are smallholder coffee producer farmers. They are major actors involved in the production and marketing of coffee. Coffee producers in the Gimbo area supply their products either to the nearest market or zonal market or traders come to the farm gate and purchase from producers. Producers have several options to sell their product: they may sell to wholesalers, retailers, processors, or others.

Wholesalers: These were those agents of the coffee marketing system who used to buy coffee in the production place with a larger volume than other actors. They are major actors in the channel, and they buy directly from individual farmers. They supply a large amount of coffee to the local and terminal markets.

Retailers: they are market actors known for their limited capacity of buying and holding products with limited financial and information capacity. They purchase coffee from wholesalers and individual farmers in their area and directly sell to consumers.

Processors: coffee processing in the study area is seemingly limited to coffee-making cafes, bars, and coffee houses. They purchase coffee from wholesalers, retailers, and individual farmers in their area, and they process it and sell to consumers.

Consumers: consumers are market actors functioning at the last stage of the coffee marketing channels. Consumers in this study mean those households who purchase and drink coffee. They are individual households; they purchase coffee from producers, wholesalers, retailers, and processors for their own consumption only.

Major coffee Marketing Channels

In the study area, there were 8 major marketing channels in which coffee was passing from producers to consumers. According to the survey result, in the study area, eight marketing channels were identified for coffee. The main receivers of coffee from coffee producers are wholesalers and retailers respectively. They get $47.5 \%$ and $22 \%$ of the total sales conducted by producers respectively. Next to wholesalers and retailers, processors are the third actors that share $17.45 \%$ of coffee supplied by growers in the study area. Consumers are identified to be the fourth important coffee purchasers from farmers in the study area in terms of volume. The major identified channels of coffee during the survey period were explained as follows (fig 1):

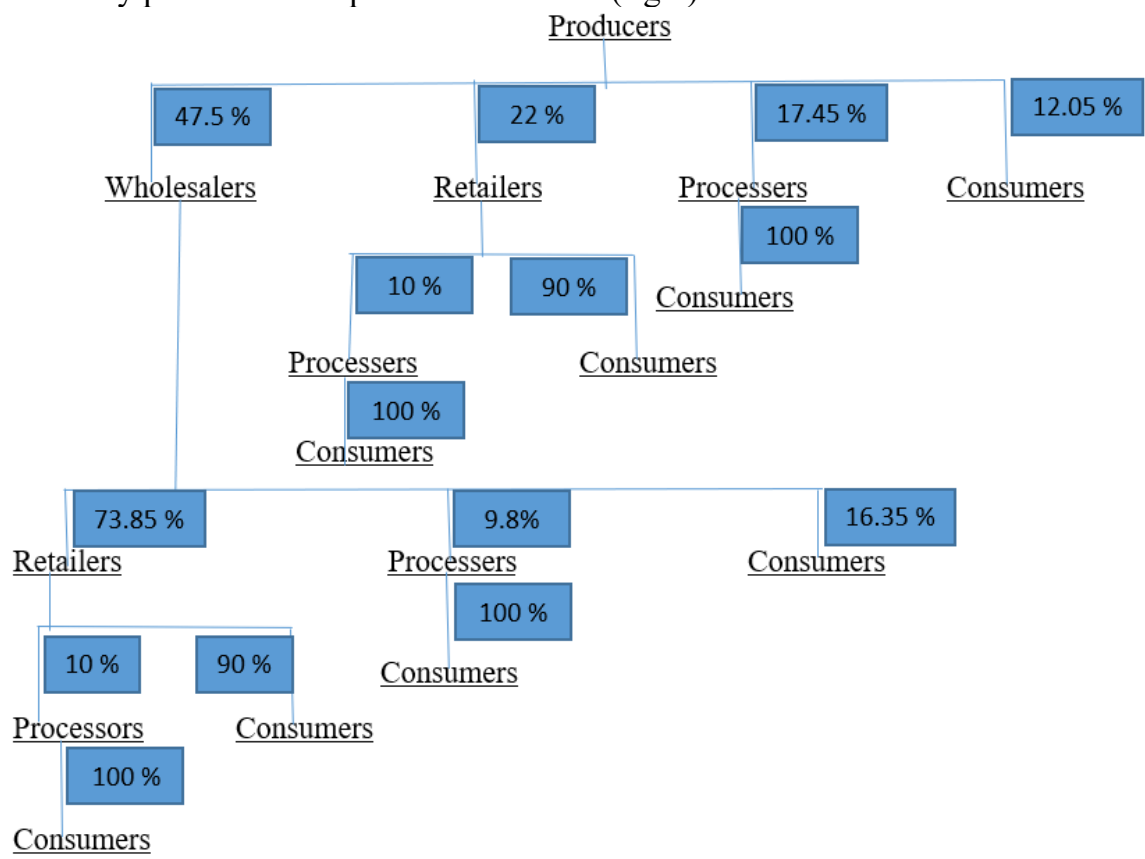

Figure 1: Coffee marketing channels

The structure-conduct-performance of coffee market in the study area Structure of the coffee market

Structure means the characteristics of the organization of a market that seems to affect the nature of competition and pricing behavior within the market. The structure of the coffee marketing system should be assessed in terms of the degree of market concentration, and the state of entry to and exit from the coffee market. The structure coffee marketing system in the study area was characterized by using market concentration, and condition of entry into and exit from the coffee market (licensing, shortage of capital, etc.). 


\section{Market concentration}

Market concentration is a function of the number of firms and their respective shares of the total production in a market. Firms frequently eliminate their competitors or discourage new firms entry to the market, contributing to more concentrated markets. In general, the higher the level of market concentration, the less perfectly competitive the market is.

The market concentration ratio measures the collective market share of all the top firms in the market. The concentration ratio is expressed in terms of CRx, which stands for the percentage of the market sector controlled by the top X firms. The degree of concentration represents the control of an individual firm or group of firms over the buying and selling of the product in the market. Four firms (CR4) concentration ratio is the most typical concentration ratio for judging the market structure (Kohls and Uhl, 1985). A CR4 of above 50\% is generally considered as strong oligopoly; CR4 between $33 \%$ and $50 \%$ is generally considered as a weak oligopoly and a CR4 of less than $33 \%$ is not a concentrated market.

In this study, major actors which participate in coffee marketing activities were taken for considering market structure. Calculation of the concentration ratio by taking an average volume of coffee handled by the top four wholesalers in the study area per week in the highest production period. The result indicated the existence of a weak oligopoly market structure in the area. Four firms control 39.7\% of the total amount of coffee sold in the market during the highest production period in Bonga town. Hence, it is decided that the coffee market in the study area was imperfect.

\section{Barrier to entry}

In the study area, there are different barriers that protect firms to enter the market. But, working capital was the main barrier which protects peoples from interring into this business. Working capital means the amount of money required by coffee traders to enter into the transaction activity. From the study result, it was observed that the majority of the sample trader's, shortage of working capital is one of the main entry barriers to enter into coffee trading. In the area, the majority of coffee traders had used their own source of capital for the trading activities. In addition, the sample respondents reported that a lack of access to credit has been the most critical constraint in the start-up and expansion of this business.

\section{Conduct of coffee market}

Market conduct refers to a firm's behavior in the market. It was studied by the pricing behavior and buying and selling practice analysis across the chain in the study area.

\section{Price setting strategy}

The survey result indicated that the price-setting technique in the coffee market is largely determined by the benevolence of purchasers. Producers have a low bargaining power to influence price because of their small supply and low access to market (price) information. According to the survey result among all respondents, more than $82.5 \%$ of the coffee producers have stated that they don't negotiate on price to sell their produce; this shows that in the study area most of the coffee producers are price takers. But the rest $17.5 \%$ of coffee producers described that coffee price decision was set by market actors through negotiation. In the direction of wholesalers, retailers, and processors, the existing demand and supply situations in the market were the major aspects they considered in setting the selling and buying price.

\section{Buying and selling strategy}

The study result shows that the majority of coffee producers $(64.7 \%)$ supply their product to the market at the time when they need money. However, the rest of the producers $(35.3 \%)$ supply their products to the market when the price of coffee rises. Most of the sellers sell their products for their clients. But the price paid by buyers for the product was the main influencing factor that affects them to whom to sell among the purchaser. The buying and selling mechanism was undertaken through cash payment. Buyers use different mechanisms in order to attract coffee suppliers (i.e. by giving credit service, pre-payment, etc.).

\section{Marketing performance}

The marketing performance in the whole chain of coffee is mainly determined by the market structure and conduct and was explained in terms of the marketing margin that each actor is taking from the final price paid by the consumers. Marketing margin means the difference in price paid to the first supplier and that paid by the final purchaser (Adegeye, 1985).

\section{Marketing margin}

Marketing margin is one of the commonly used measures of marketing performance. It is defined as the difference between the price paid by the consumers and the price received by the producers. However, it may also describe price differences between different actors in the marketing chain, for example, between producer and wholesaler prices, wholesaler and retailer prices, retailer and processer prices, etc. Calculating the total gross marketing margin is always related to the price paid by the end consumer.

Therefore, in this study coffee marketing margins were calculated based on the average sale price of different marketing actors in the area. Overall marketing margins of coffee marketing channels were described below: 


\begin{tabular}{lc} 
Market chain participants & selling price \\
\cline { 1 - 2 } Producers & 65 \\
Wholesalers & 80 \\
Retailers & 90 \\
Processers & 115
\end{tabular}

Processers

GMMws $=[($ wholesalers price - producer price $) /$ consumer price $] * 100$

$$
=\frac{80-65}{115} * 100=\frac{15}{115} * 100=13.04 \%
$$

$\mathrm{GMMr}=\frac{\text { Retailers price }- \text { Wholesalers }}{\text { consumers price }} * 100=\frac{90-80}{115} * 100=\frac{10}{115} * 100=8.70 \%$

$\mathrm{GMMp}=\frac{\text { Processers price-Retailers price }}{\text { consumers price }} * 100=\frac{115-90}{115} * 100=\frac{25}{115} * 100=21.74 \%$

$\mathrm{TGMM}=\mathrm{GMMws}+\mathrm{GMMr}+\mathrm{GMMp}=13.04+8.70+21.74=43.48 \%$

GMMpr $=100-43.48=56.52 \%$

Where: GMMws = Gross marketing margin of Wholesalers

$\mathrm{GMMr}=$ Gross marketing margin of Retailers

GMMp $=$ Gross marketing margin of Processers

GMMpr $=$ Gross marketing margin of Producers

Generally, the total gross marketing margin added to the coffee price when it passes through the marketing channels was $43.48 \%$. As can be seen from marketing margin analysis, producers are highly benefiting from the final price paid by the end consumers $(56.52 \%)$ as compared with other marketing actors. And out of the total gross marketing margin of coffee, $43.48 \%$, Processers received the highest of all marketing actors which is $21.74 \%$. The rest $13.04 \%$ and $8.70 \%$ of marketing margin were received by wholesalers and retailers respectively

\section{Econometric Results}

\section{Determinants of Coffee Market Supply}

Coffee was an important cash crop and mainly produced for the market in the study area. The study result shows that all sample coffee producers were supplying their products during the investigation period. In order to identify those factors which affect the volume of coffee supplied by producers to the market, analysis of factors that affect the level of farmers' participation in the coffee market was found to be significant.

Multiple linear regressions model analysis was used to analyze factors that affect the level of farmer's participation in the coffee market. Before running the model, the hypothesized independent variables were checked for the existence of multicollinearity and heteroscedasticity problems. The study used the Variance inflation factor (VIF) to check the degree of multicollinearity among continuous independent variables and contingency coefficient (CC) among dummy variables. Both the VIF and CC values indicate that there no multicollinearity problem among independent variables. The heteroscedasticity test result also shows that there is no heteroscedasticity problem in the data set.

\section{Econometric results of the OLS model}

Eleven explanatory variables were hypothesized to analyze factors that affect the level of farmer's participation in the coffee market. Among these variables, only two variables (Income from off-farm activities and Quantity of coffee produced) were found to significantly affect the level of coffee market participation. The remaining nine variables have no significant effect on the level of coffee market participation.

Quantity of coffee produced: as expected, this variable was found to have positively and significantly affected the level of coffee market participation at a $1 \%$ significant level. A positive coefficient implies that an increase in the quantity of coffee produced increases the volume of the marketable supply of coffee by producers. It indicates that households that produce more quantity of coffee had also supplied more to the market. As the result shows that when the amount of coffee production increase by one unite the level of coffee market participation increase by 0.86 unit. In line with this, the study conducted by Zekarias et al. (2012), found that the amount of coffee production significantly and positively influenced the level of coffee market participation. This implies that as the coffee yield increases, the level of market participation also increases.

Income from off-farm activities: deviate from the hypothesis, this variable was positively and significantly affects the quantity supply of coffee at a 5\% significance level. The positive coefficient indicates that a unit increase in income obtained from non-farm activities will increase the level of marketable supply of producers. The result also implied that a unit increase in the income from non-farm activities has caused an increase of 0.07 units of marketable coffee. The result also has shown that off-farm income has improved the producing household ability to acquire improved technologies in relation to coffee production and marketing, which in turn enhanced farmer's productivity and market participation and thereby increased marketable supply of coffee. 
Table 3. OLS estimation results of determinants of coffee market supply

\begin{tabular}{|l|l|l|l|}
\hline Variables & Coef. & Std. Err. & P>t \\
\hline Age of HHH & .0002419 & .0013594 & 0.859 \\
\hline Sex of HHH & -.0361777 & .0344399 & 0.295 \\
\hline Education states of HHH & .0015411 & .0331885 & 0.963 \\
\hline Transportation facility & -.0137853 & .0328411 & 0.675 \\
\hline Family size & .0025127 & .0108045 & 0.816 \\
\hline Off farm income & .0720672 & .0318008 & $0.025^{* *}$ \\
\hline Land size & .0106773 & .0256224 & 0.678 \\
\hline Total livestock & .0181217 & .011903 & 0.130 \\
\hline Quantity produced & .8611109 & .01654 & $0.000^{* * *}$ \\
\hline Distance & -.0133703 & .0157697 & 0.398 \\
\hline Information & .0314082 & .0341791 & 0.360 \\
\hline cons & -.1560008 & .0981647 & 0.114 \\
\hline
\end{tabular}

Source: Survey result, 2020

$* * *, * *$, and $*$ show the value statistically significant at $1 \%, 5 \%$ and $10 \%$ respectively.

\section{CONCLUSION AND RECOMMENDATION}

The study was conducted in Gimbo woreda, Kaffa zone, SNNPR, and Coffee is a very important cash crop in the area. The study was undertaken with the general objective of market chain analysis of coffee production in Gimbo woreda, Kaffa zone, SNNPR, Ethiopia. According to the information obtained from the study indicates that an average of 1.62 quintals of coffee was produced by the sampled households. The study also identified the main marketing actors through whom the coffee product was moved from producer to final consumers, which are producers, wholesalers, retailers, processors, and consumers. Accordingly, in the study area coffee producers supplied $47.5 \%$ of their coffee products to wholesalers, $22 \%$ to retailers, and $17.45 \%$ to processers, and 12.05 to consumers during the study period.

The result of the assessment of the market structure indicated that the four firm's concentration ratio (CR4) was $39.7 \%$, which shows there is a weak oligopoly in the market structure of coffee in the area.in the area lack of working capital was the main barrier which protects peoples from interring in this business. The survey result indicated that the price-setting technique in the coffee market is largely determined by the benevolence of purchasers. Producers have a low bargaining power to influence price because of their small supply and low access to market (price) information. The study result shows that the majority of coffee producers (64.7\%) supply their product to the market at the time when they need money. In evaluating the market performance, the marketing margin analysis result showed that processers $(21.74 \%)$ take the largest marketing margin in the coffee market chain. The rest $13.04 \%$ and $8.70 \%$ of marketing margin were received by wholesalers and retailers respectively.

To identify factors influencing the level of coffee market participation in the study area, ordinary least square regression was employed. Eleven explanatory variables were hypothesized to analyze factors that affect the level of farmer's participation in the coffee market. The OLS analysis result shows that Among Eleven explanatory variables, only two variables (Income from off-farm activities and Quantity of coffee produced) were found to significantly affect the level of coffee market participation. The remaining nine variables have no significant effect on the level of coffee market participation.

Coffee production and marketing provides job opportunities for many peoples. Main people need to participate in the coffee marketing business, but they are unable to participate in this business because of a shortage of capital. The quantity of coffee produced affects the level of coffee market participation positively and significantly. However, coffee production and productivity in the area are still low compared to the world and regional average. Farmers are working under limited capital as well as socio-economic factors without using improved technologies and agricultural inputs. Hence, increasing production and productivity of coffee is a better alternative to increase the marketable supply of coffee. Off-farm income also positively and significantly affects the marketed supply of coffee. Off-farm income gives farmers the ability to get improved technologies, different agricultural inputs, and marketing facilities.

So, the government, Agricultural offices, universities, research institutes, and other bodes must try to solve this problem through different mechanisms like giving subsidies, creating easy ways to gate credit, creating offfarm activities, etc. Agricultural offices should create awareness among coffee producers to allocate appropriate land, labor, capital, and time for coffee production and to produce coffee in irrigation as of other cash crops. 


\section{REFFERENCE}

Adegeye A, and Dittoh J. (1985), Essentials of Agricultural Economic. Impact Publisher, Ibadan, Nigeria Ltd. pp. 164-177.

Aklilu A. and Ludi E. (2010), The Effect of Global Coffee Price Changes on Rural Livelihoods and Natural Resource Management in Ethiopia: A Case Study from Jimma Area. NCCR North-South Dialogue 26. Bern, Switzerland: NCCR North-South.

Central statistical agency (CSA), (2017). Agricultural sample survey 2016/2017 (2009 E.C). Volume I report on area and production of major crops (private peasant holdings, Meher season), Addis Ababa.

Demeke, T. (2007), Performance of coffee marketing co-operatives and members ${ }^{e e}$ satisfaction in Dale district: Southern Ethiopia. MSc Thesis, Haramaya University, Haramaya, Ethiopia. Retrieved from http://citeseerx.ist.psu.edu/viewdoc/download;jsessionid=0B049800B53E 4EFA8C29797B6D5B2542?doi=10.1.1.608.1592\&rep=rep1\&type=pdf.

Ethiopian Coffee Exporters (ECX), (2011), a market to transform Ethiopia. Ethiopian commodity exchange monthly newspaper. 1(4-5).

Ethiopian Coffee Exporters Association (ECEA), (2013), Coffee export marketing in Ethiopia. Annual report. ECEA, Addis Ababa, Ethiopia.

FAO. (2011), "Resilient Livelihoods. Disaster Risk Reduction for Food and Nutrition Security Framework programme" Rome.

Greene, W. (2000), Econometric Analysis. 4th edn. NJ: Prentice Hall, Englewwod Cliffs.

Gujarati, D. (2003), Basic Econometrics. 4th edition. Tata McGraw-Hill Publishing Company Limited, New Delhi, India. $614 \mathrm{p}$.

Kohl, R.L. and Uhl, J.N. (1985), Marketing of Agricultural Product, 5th Edition, Collier Macmillan, USA. 624p.

Jari, B. and Fraser, G. (2009), 'Analysis of institutional and technical factors influencing agricultural marketing among smallholder farmers in Kat River Valley', African Journal of Agriculture, 4 (11), 1129-1137.

Jema Haji. (2008), Economic efficiency and marketing performance of vegetable production in the eastern and central parts of Ethiopia.

LeRoux, M.N., T.M. Schmit, M. Roth, and D.H. Streeter. (2010), "Evaluating Marketing Channel Options for Small-scale Fruit and Vegetable Producers." Renewable Agriculture and Food Systems 25, no. 1: 16-23. Accessed September 29, 2020. http://www.jstor.org/ stable/ 44490620.

Mendoza G. (1995), A Primer on marketing channels and margins. Lyme Rimer Publishers Inc., USA. 425p.

MoT. (2012), This report contains assessments of commodity and trade issues made by USDA staff and not necessarily statements of official U.S. government policy; approved by Quinton Gray and Prepared by, Abu Tefera and Teddy Tefera.

Panda, R. and Sreekumar. (2012), Marketing Channel Choice and Marketing Efficiency Assessment in Agribusiness, Journal of International Food \& Agribusiness Marketing, 24:3, 213-230, DOI: 10.1080/089 74438. 2012.691812.

Scarborough, V. and J. Kydd. (1992), Economic analysis of agricultural markets. A manual of marketing series 5 , Chatham, UK: Natural Resource Institute: 172p.

Shilpi, F. and Umali Deininger, D. (2008), Market Facilities and Agricultural Marketing: Evidence from Tamil Nadu, India. Agricultural Economics, 39, 281-294. https://doi.org/ 10. 11 11/j.1574-0862.2008.00333.x

Tinsae Demmisse. (2008), 'Marketing performance of primary coffee Cooperatives in Wonago and Yirgacheffe woreda' SNNP, M.Sc. Thesis, Haramaya University, Haramaya, Ethiopia.

Zekarias S., Kaba U. and Zerihun K. (2012), Analysis of Market Chains of Forest Coffee in Southwest Ethiopia. [Online] Semanticscholar.org. Available at: $<$ https://www. semanticscholar.org/paper/Analysis-of-MarketChains-of-Forest-Coffee-in-Shumeta Urgessa/ceba09977aebf7998 b75299034981bb9430e9205. 